\title{
Tıp Tarihyazımı: Karşıtlıklar, Etkileşimler
}

\section{Medical Historiography: Controversies, Interactions}

\author{
Ceren İlikan Rasimoğlu ${ }^{1}$ (]
}

'Dr. Öğr. Üyesi, Acıbadem Üniversitesi, FenEdebiyat Fakültesi Sosyoloji Bölümü, Istanbul, Türkiye

\section{ORCID: C.I.R. 0000-0001-7586-4813}

Sorumlu yazar/Corresponding author: Ceren İlikan Rasimoğlu,

Acıbadem Üniversitesi, Fen-Edebiyat Fakültesi,

Sosyoloji Bölümü, İstanbul, Türkiye

E-posta/E-mail: cerenilikan@gmail.com

Başvuru/Submitted: 17.09.2019

Revizyon Talebi/Revision Requested:

17.09.2019

Son Revizyon/Last Revision Received:

30.09.2019

Kabul/Accepted: 10.05 .2020

Online Yayın/Published Online: 03.07.2020

Atıf/Citation: Ilikan Rasimoğlu, Ceren. "Tıp Tarihi Yazımı: Karşıtıılar, Erkileşimler." Osman/ı Bilimi Araştırmaları 21, 2 (2020): 347-367. https://doi.org/10.26650/oba.621210

\section{öz}

Bu makalenin amacı, on dokuzuncu ve yirminci yüzyıllarda Batı Avrupa ve Amerika Birleşik Devletleri'nde tıp tarihçiliğinin temel aşamalarına genel bir bakış sunmaktır. Makale, klasik olarak tanımlanan ve öncelikle hekimler tarafından kaleme alınan klinik tarihçilik ile özellikle 1970'lerden beri sosyal bilimciler tarafından öne sürülen tıbbın sosyal tarihinin etkileşimini ele almaktadır. Makalede, bilimsel ve tıbbi gelişmeler, sosyal olaylar ve tutumlar arasındaki ilişki incelenerek bunların sosyal bilimler ile etkileşimi ve tıbbın tarihinin çeşitli yazım biçimleri tanımlanmaktadır. Makalenin ana odak noktası, beden ve toplum arasındaki ilişkinin dönüşümü ile hastalık ve sağlık tarihinin dönüşümü arasındaki ilişkidir. Bu çalışma, tıp tarihi yazımının farkı disiplinlerden araştırmacıların konuyu kendi perspektiflerinden tartıştı̆ını göstermiştir. Başlangıçta, tıbbın ilerleme tarihi olarak görülen tıp tarihinin yazarları hekimler iken, zamanla sosyal bilimciler de bu alana kaymıştır. Sosyal tıp tarihçiliğinin haricinde hem yeni teknolojiler hem de tıbbın yeni biçimlerde değerlendirilmeye başlanması sonucunda tarih, etik, sosyoloji, bilim ve teknoloji çalışmaları gibi alanlar çeşitli işbirliği zeminleri arayışına girmişlerdir.

Anahtar sözcükler: Tarihyazımı, tıp tarihyazımı, sosyal tıp tarihi, klinik tıp tarihi, tip tarihi

\section{ABSTRACT}

This article aims to present a general overview of the basic stages of medical historiography in Western Europe and the United States during the nineteenth and twentieth centuries. The framework of the article is formed by the interaction of a clinical historiography, which is defined as classical and practiced primarily by physicians; and the social history of medicine, which has been put forward by social scientists, especially since the 1970 s. Because the history of medicine was primarily regarded as the history of the evolution of medical knowledge, the early authors were physicians. The points of interaction with social sciences and several historiographies of medicine are identified in the article by examining the relationship between the scientific and medical developments, social events and attitudes. The main focus of the article are the ways of change of the history of illness and health by the transformation of the relationship between body and society.

Keywords: Historiography, medical historiography, social history of medicine, clinical history of medicine, medical history 
"Tıp tarihi birçok şekilde yazılabilir. İlginç bir ilerleme masalı olarak anlatılabilir, tuhaf ve korkunç uygulamaların iç gıcıklayıcı ayrıntıları nakledilebilir ya da benim burada yaptığım gibi, geçmişi kendi bağlamında ele alıp, tıp tarihi ile tarihin akışı ve tıp ile toplum arasındaki bağları vurgulamak da mümkün."”

$\mathrm{Bu}$ makale, on dokuzuncu ve yirminci yüzyıllarda Batı Avrupa ve Amerika'da tıp tarihinin geçirdiği temel aşamaları betimsel bir yöntemle aktararak klinik tıp tarihi ile sosyal tıp tarihi arasındaki temel yaklaşım farklılıklarına odaklanmaktadır. Makalede, pozitivizm ve modernleşme paradigmaları ile tıbbın tarihinin yazılma biçimleri arasındaki ilişki incelenecek ve bu ilişkinin eleştirel gözle yeniden ele alınmasına zemin hazırlayan gelişmeler tartışılacaktır. Geleneksel tarihyazımının temel nitelikleri özetlendikten sonra, yeni tarihçiliğin getirdiği kuramsal eleştirilerin anlatılacağı makalenin ikinci bölümünde ise tıp tarihyazımının klasik ve çağdaş biçimleri ele alınacak, genel tarihyazımı ile arasındaki ilişki, benzerlikler ve farklılıklar değerlendirilecektir. Yazının temel vurgusu, tıp tarihyazımının kendi doğası ${ }^{2}$ gereği genel tarihçilikten ayrı düşünüldüğü ama aynı zamanda genel tarihçiliğin yaklaşımları ile desteklendiğinde kapsayıcı bir tıp tarihi anlayışı ortaya koyduğudur.

Tıp tarihyazımının profesyonel bir disiplin olarak ortaya çıkışından itibaren geçirdiği değişim, alandaki temel eserlere atıfta bulunularak konu edilecek ve yeni tarihçiliğin ve sosyal teorilerin sosyal tıp tarihyazımına etkisi vurgulanacaktır. Makale, tıp tarihyazımının tarihsel izleğinin bütününü kapsamayı değil, sadece sosyal tıp tarihyazımının hangi koşullarda, ne amaçlarla, kimler tarafından üretildiğinin; sosyal teorilerin ne tür kavramsal araçlarından faydalanıldığının kuşbakışı resmini çizmeyi amaçlamaktadır. Yeni tıp tarihçiliğinde kültürel tıp tarihi; bilim, teknoloji ve tıp çalışmaları gibi alanlar bu yazının kapsamı dışında tutulmuştur.

\section{Profesyonelleşen Tarihçilik}

Tarih disiplininin on dokuzuncu yüzyılda bir uzmanlık alanı olmasının altında yatan temel düşünce, tarihin bir "bilim” olduğu iddiasıydı ve tarih araştırmaları giderek üniversitelerde ve araştırma merkezlerinde yoğunlaşmaya başlamıştı. ${ }^{3}$ Elbette tarihçiler doğa bilimciler gibi soyutlama ve genellemelere dayanan bir bilim anlayışını tarih disiplinine bütünüyle uygulayamasalar da bu anlayışa yakın olabilmenin anahtarı olarak nesnelliği görüyorlardı. ${ }^{4}$ Diğer bilim insanları gibi hakikat arayışı içindeydiler ve bilginin nesnellik vasıtasıyla üretilebileceğini düşünüyorlardı. Dolayısıyla tarih, on dokuzuncu yüzyıl Alman tarihçi

1 Mary Lindemann, Erken Modern Avrupa'da Tip ve Toplum, çev. Mehmet Doğan (İstanbul: Boğaziçi Üniversitesi Yayınevi, 2013), 339.

2 Burada doğadan kasıt, ürettiği bilgi biçiminin sosyal bilimlerden farklı oluşu ve insan bedeni ve doğaya ilişkin ayrı bir bakış açıcı ve bilgi gerektirmesidir.

3 Georg G. Iggers, Bilimsel Nesnellikten Postmodernizme Yirminci Yüzyılda Tarihyazımı, çev. Gül Çağalı Güven (İstanbul: Tarih Vakfi Yurt Yayınları, 2000), 1.

4 Fatih Yazıc1, "Tarihte Nesnellik ve Nedensellik," Tarih İçin Metodoloji, yay. haz. Ahmet Şimşek (Ankara: Pegem Yayınları, 2016) içinde, 15-23. 
Leopold von Ranke'nin ifade ettiği gibi “olayların tam da vuku bulduğu gibi” anlatılması anlamına geliyordu. Bu anlayış, profesyonel tarihçiler ile amatör hikâye anlatıcıları arasında ayrım yapılmasıyla sonuçlanıyor, bu da nesnel olduğu düşünülen bir şekilde olayların aktarılmasının temel yöntem olarak kabul edilmesiyle gerçekleşiyordu.

Yine de on dokuzuncu yüzyıl tarihyazımı, M.Ö. 5. yüzyılda yaşamış tarihçi Atinalı Thukidides’ten itibaren benzer bir geleneği takip ediyordu. Thukidides, mit ile gerçek ayrımını öneren kişiydi. Bu çizgi Antik Yunan'dan beri devam etmiş ve Ranke ile sistematize edilip akademik hayata dâhil edilebilmişti. Bu gelenek, eylemlerin tarihsel aktörlerin niyetlerini ortaya koyduğunu düşünüyor ve çizgisel, silsile halinde birbirini izleyen olaylar örgüsü tahayyül ediyordu. Bu anlayış yirminci yüzyılın ikinci yarısına dek tarihçiliğin temel çerçevesini çizmişti. ${ }^{5}$

Geleneksel tarihyazıcılığının bir diğer niteliği, tarihe konu olabilecek kişilerin tek tip olmasıydı: Krallar, din adamları, savaşçılar, bilim adamları gibi “büyük adamlar"ın siyasal ya da mesleki başarılarının tarihi yazılabiliyor; tarih onların gözünden, onların hoşuna gitmek için, onların hikâyelerini yadsınamaz ve sorgulanamaz gerçekliklermiş gibi anlatıyordu. Aynı zamanda Batı uygarlığı ve tarihi, tarihyazımının temel konuları ve referans noktaları olarak görülmekteydi. Diğer bir deyiş̧le tarihin belli bir döneminde Batı'da ortaya çıkan bir gelişmenin er ya da geç daha geride olduğu düşünülen Batı dışı toplumlarda da görüleceği varsayılıyordu. Dolayısıyla tarihçiler genel olarak modern çağın belli bir doğrultuda, benzer biçimde ve geri dönüşsüz bir şekilde aktığına inanıyorlardı.

Yirminci yüzyılın başlarından itibaren sosyal bilim çevrelerinde "büyük kişiler”, "büyük olaylar" odaklı ve "ilerlemeci" tarih anlayışını sorgulayan çeşitli gruplar ortaya çıkmaya başlamıştı. Bu gruplar olay yönelimli tarihçiliği eleştiriyor, aktörlerin ve aktörler arasındaki ilişkilerin tarih anlatılarına davet edilmeleri gerektiğini söylüyordu. Yüzyıl dönümünde dünyanın pek çok yerinde tarihçiler bu paradigmayı eleştirmeye başlamıştı; toplumsal ve ekonomik bakış açılarını göz önünde bulundurarak tarihi yalnızca bir siyasi olaylar silsilesi olmaktan çıkarmaya çalışıyorlardı. Böylelikle tarih, büyük adamlara ve tek tek olaylara odaklanmaktan ziyade toplumsal, kültürel ve politik koşullar değerlendirilerek yazılacak ve sıradan insanlar anlatılara dâhil edilecekti. İngiltere'de Marksist tarihçiler ile Fransa'da Annales ekolünün başını çektiği eleştirel gruplar özellikle İkinci Dünya Savaşı'ndan sonra sistematik olarak tarihin yazılış biçimlerini değiştirmek için çalışmalar yapmış, Annales ve Past and Present gibi dergiler yoluyla seslerini duyurmuşlard1.

Geleneksel tarihyazımını eleştirenlerin temel amaçları, hem tarihi yazanlar hem de bakış açısı çerçevelerinde tarihi demokratikleştirmekti. Bu anlayışın önemli bir sonucu, "büyük anlatı"ların son bulmasıydı. Artık Batı, çeşitli uygarlıklardan sadece biri olarak görülmeye

5 Iggers, Bilimsel Nesnellikten Postmodernizme, 1-3. 
başlanmıştı. Marc Bloch ve Fernand Braudel çizgisel tarih anlayışından makro ve mikro tarih anlayışına yol almış, analiz birimi olarak uluslardan ziyade Akdeniz ya da belirli bir köy gibi coğrafyalara odaklanmışlard1 ${ }^{6}$ Edward Palmer Thompson tarih anlatılarında avamın bakış açısını merkeze alıyordu. 7 "Aşağıdan tarih" adı verilecek olan bu yaklaşım, "önemli insanlar" 'n dışında kalan; yoksul, marjinal, sıradan insan gibi tabirlerle anılacak olan insanları tarih anlatılarına dâhil ediyordu. Özellikle kadınlar ve marjinal grupların dâhil edilmesi, yeni tarihçilik anlayışlarının ortaya çıkmasıyla sonuçlandı.

Yeni tarihçiliğin savunucuları tarih dışındaki sosyal bilim alanlarıyla dirsek temasında bulunuyor, anlatılarının kuramsal temellerini bu disiplinlerin aracılığıyla oluşturuyordu. ${ }^{8}$ Antropoloji, sosyoloji, siyaset bilimi, felsefe gibi alanlar, tarihin belirli bir dönemindeki toplumsal ve kültürel örüntüleri anlamlandırmaya yardım ediyordu. Böylelikle yeni tarihçilik kuramsal zeminden yoksun bir anlatımdan kaçınıyordu. Buna paralel olarak, tarihin nesnelliği iddiası da temelinden sarsılmış oluyordu. Tarih, zamanın belirli bir döneminde yaşanan olayların belirli -öznel- bir perspektiften yorumlanmasıydı. Dolayısıyla tarihçi ortaya çıkardığı esere kendini de katmaktaydı. Ranke'nin değer yargılarından uzak durulmasına yönelik önerisi bütünüyle alaşağı ediliyor; bilakis araştırmacının değer yargıları (anakronizm tehlikesinin farkında olunmak kaydıyla) tarihsel dönem, araştırma konusu ve araştırılacak aktörler dahil olmak üzere tüm tarihyazımına sirayet ediyordu. Konu seçilirken ve daraltılırken, belgeler seçilirken, seçilmiş olan belgeler anlamlı bir hikâye oluşturacak şekilde yeniden kurgulanırken tarihçinin kimliği her zaman belirleyiciydi, nihayetinde insan hikâyesini anlatan yine bir insandi. Bu nedenle kendisi dışındakilerin hikâyesini anlatan, bu hikâyeleri belirli kurallara bağlamaya çalışan tarihçi için, doğa bilimlerinde olduğu gibi bir nesnellik asla söz konusu olamazdı.

\section{Modern Tıbbın Ortaya Çıkışı ve Klinik Tıp Tarihi}

İlk bakışta tıp tarihini genel tarihçilikten farklı kılan özellik, eserlerin çoğunlukla tarihçiler değil hekimler tarafından yazılmış olmasıdır. On sekizinci yüzyıl sonlarında tıbbın tarihi, hekimlerin ve -kimi zaman bilim insanlarının- seleflerinin bilimsel faaliyetlerini aydınlatmak ve unutulmuş olan tedavi yöntemlerini yeniden su yüzüne çıkarmak için yazılmaktaydı. Yirminci yüzyılın ilk çeyreğine kadar hekimler haricindeki sağlık çalışanları, hastalar, toplum, devlet gibi sağlık alanının diğer aktörleri tıbba ilişkin tarihsel anlatılarda kendilerine yer bulamıyor, bulsalar dahi tali konumlara yerleştiriliyorlardı. Buradaki en temel sav, genel tarihin aksine tıbbi bilgiye hâkim olma gerekliliğiydi; dolayısıyla sağlık ve tıp söz konusu olduğunda hiyerarşinin en üstünde yer aldığ kabul edilen hekimler, tıbbın tarihini yazmanın meşru ve yegâne adayları olarak görülüyordu.

6 Peter Burke, Fransız Tarih Devrimi: Annales Okulu, çev. Mehmet Küçük (Ankara: Doğubat1, 2010).

7 Edward Palmer Thompson, Avam ve Görenek: Ingiltere'de Geleneksel Popüler Kültür Üzerine Araştırmalar, çev. Mehmet Küçük (İstanbul: Birikim Yayınları, 2006).

8 Zafer Toprak, "Sosyal Tarih," Tarih İçin Metodoloji, yay. haz. Ahmet Şimşek (Ankara: Pegem Yayınları, 2016) içinde, 142-150. 
Tıp tarihinin konularını ise konu aldığı kişiyi yüceltmek için yazılan hekim biyografileri (tıbbın "büyük adamları”) ya da klasik tarihyazımının çizgisel/ilerlemeci yaklaşımıyla paralellik teşkil edecek şekilde tıbbi ve bilimsel ilerlemeler oluşturabiliyordu. Özellikle on dokuzuncu yüzyılda tıpkı pozitivizmin etkisiyle nesnellik arayışında olan tarihçiler gibi, hekimler tarafından ortaya atılan doğrulanabilir tıbbi bilgi tıp tarihçileri tarafından da benimsenmişti. ${ }^{9}$ Tıptaki ilerlemeler bilimsel nesnellik iddiasını da barındıracak şekilde yüceltiliyordu.

On dokuzuncu yüzyılın ikinci yarısında patolojik anatomi alanındaki gelişmeler, mikroskobun yaygın olarak kullanılması ve enfeksiyon kavramı; toplumsal anlamda bedenin tıbbileştirilmesini temellendirmeye yaramış, bilimsel anlamda ise önleyici tıp ve cerrahide gelişmeye sebebiyet vermişti. Erken yirminci yüzyılda tıbbi ve cerrahi hizmetler, savaş deneyimleri ile beraber daha da gelişmiş ve yaygınlaşmıştı. 1910 yılında akut enfeksiyona karşı uygulanan ilk tedavi olan Salvarsan'ın frengi hastalığında, 1922'de insülinin diyabet tedavisinde, 1924'te B.C.G.'nin tüberküloz için kullanılmaya başlanması gibi gelişmeler, antibiyotikleri ve bakteriyostatikleri yeni tıbbın silahları haline getirmişti. ${ }^{10}$

Tıbbi ilerlemeye yoğunlaşmayı, nesnel tarihçiliğin bir gereği ya da yöntemi olarak düşünen dönemin tıp tarihçileri, tıbbi uygulamaların ya da gelişmelerin arkasındaki sosyal ve kültürel örüntülere odaklanmaktan uzaktı. Biyografik bilgi toplanmasına dayalı tıp tarihçiliği on sekizinci yüzyıl sonlarından itibaren giderek yaygınlaştı. Dönemin önemli isimlerinden ve akademik tıp tarihçiliğinin öncülerinden Kurt Sprengel'e göre verilerin toplanması ve sunumu, tarihçiliğin çekirdeğini oluşturmaktaydı ve bilimde ilerleme ancak verilerin birikimi ile mümkündü. Dolayısıyla hekimler seleflerinin icraatları hakkında bilgi sahibi olmalıydılar. ${ }^{11}$

Almanya'da neo-Hümanizm ve Romantizmi yansitan Spengler'dan mülhem eserler üretilirken, aynı dönemde Fransa Auguste Comte'un çalışmalarıyla şekillenen pozitivist bir gündemi takip etmekteydi. Fransız kütüphaneci, filolog ve tıp tarihçisi Charles Victor Daremberg, ${ }^{12}$ hekimleri tıbbın tarihini yazmaya teşvik etmekte, bilim devrimi fikri hekimler arasında yaygınlaşarak edebiyat ve tarihin tıp müfredatına eklenmesi düşüncesini güçlendirmekteydi. ${ }^{13}$ Öte yandan, tıp tarihi yazmak, pozitivizmin yanı sıra dönemin

9 Steven Cherry, Medical Services and the Hospitals in Britain, 1860-1939 (Cambridge \& New York: Cambridge University Press, 1996), 17.

10 A.g.e., $18-19$.

11 Hans-Uwe Lammel, "To Whom Does Medical History Belong? Johann Moehsen, Kurt Sprengel, and the Problem of Origins in Collective Memory," Locating Medical History: The Stories and Their Meanings, yay. haz. Frank Huisman ve John Harley Warner (Baltimore \& London: The Johns Hopkins University Press, 2004) içinde, 36-47.

12 Danielle Gourevitch, "Charles Victor Daremberg (1817-1872) et une Histoire positiviste de la Médecine," erişim 26 Nisan 2020, http://www.biusante.parisdescartes.fr/histoire/medica/daremberg.php.

13 Danielle Gourevitch, "Charles Daremberg, His Friend Emile Littré, and Positivist Medical History," Locating Medical History: The Stories and Their Meanings, yay. haz. Frank Huisman ve John Harley Warner (Baltimore \& London: The Johns Hopkins University Press, 2004) içinde, 67. 
faydacılığı ile de örtüşüyordu; hâlihazırdaki tıbbi uygulamaları anlamak için kadîm tıbbı öğrenmek önemli ve yararlı bir uğraştı. ${ }^{14}$

Yüzyıl dönümünde modernleşmeci paradigmayı takip eden Julius Pagel, Max Neuburger ve 1905 yılında Almanya'da ilk defa akademik kadroya sahip olmuş tıp tarihçisi olan Karl Sudhoff ${ }^{15}$ pozitivizmi ve faydacılığg benimsemişlerdi. Julius Pagel hekimler üzerine bina edilen bir tıp tarihi yaratma çabası ile biliniyordu. Pagel'a göre tarih, unutulmuş devaların yeniden bulunabilmesine yardım edebilecek ve hekimlerin ticari kaygılarla hareket etmesini engellemeye katkıda bulunacaktı. ${ }^{16}$ A.B.D.'de yayımlanmış ilk büyük tıp tarihi eseri kabul edilen, Fielding H. Garrison'un 1914 yılında basılan An Introduction to the History of Medicine (Tıp Tarihine Giriş) başlıklı eseri, büyük insanların tarihini anlatmaktaydı. Garrison'un iddiası, tıp öğrencilerine ve hekimlere, mesleki hayatlarında gerekli olabilecek ya da tıbbi kültürlerine katkı sağlayabilecek önemli olayları aktarabilmekti. ${ }^{17}$

Tıp klasiklerini toplayarak büyük bir kütüphanenin oluşmasını sağlayan, teknik gelişmelere ve mesleki kimliğin inşasına dayalı bir tıp tarihi anlayışının harcını oluşturan kişi ise William Osler'di. Osler verdiği derslerde, hekim adayı öğrencilere tıbbi biyografinin kariyerleri için parlak olasılıklar ve örnek alınabilecek hayatlar sunabileceğini anlatıyordu. ${ }^{18}$

Osler'in yaklaşımına benzer biçimde tıp eğitiminde tıp tarihinin gerekliliğini ve önemini savunan Max Neuberger, Viyana Üniversitesi’nde vermekte olduğu tıp tarihi derslerinin amacını ve faydasını şu şekilde tarif ediyordu:

Öğrencilerin yüreklerinde tıp tarihi hekimlik sanatı, etik ve mesleğin genel ethosuna dair bir şevk yeşermesine sebep olmuş; felsefi ve kültürel tarih bilincini geliştirmiş ve genç hekimleri entelektüel yalnızlıktan kurtarmıştır. Tıp tarihi eski çalışmaların araştırılması yolu ile bilimin temellerine dair bir anlayış beslemiş ve bu eski çalışmalar nedeniyle geçmiş, geleceğe dair kavramların oluşturulması için gerekli donanımı sağlamıştır. Geçmişe dair bilgi, mevcut tıbbın birbirinden ayrılan gerçeklerin oluşturduğu ve modern tıbbın amaçlarına ve araçlarına isabet eden karmaşık mebzuliyetin kilidini açmak için bir anahtar görevi yapmaktaydı. ${ }^{19}$

14 Vivian Nutton, "Ancient Medicine: From Berlin to Baltimore," Locating Medical History: The Stories and Their Meanings, yay. haz. Frank Huisman ve John Harley Warner (Baltimore \& London: The Johns Hopkins University Press, 2004) içinde, 116.

15 John V. Pickstone, A Brief History of Medical History, erişim 17 Eylül 2019, http://www.history.ac.uk/ makinghistory/resources/articles/history_of_medicine.html.

16 Heinz-Peter Schmiedebach, "Bildung in a Scientific Age: Julius Pagel, Max Neuburger, and the Cultural History of Medicine," Locating Medical History: The Stories and Their Meanings, yay. haz. Frank Huisman ve John Harley Warner (Baltimore \& London: The Johns Hopkins University Press, 2004) içinde, 75, 80-83.

17 Charles R. King, "The Historiography of Medical History: From Great Men to Archaeology," Bulletin of the New York Academy of Medicine 67, 5 (1991): 409.

18 Elizabeth Fee ve Theodore M. Brown, "Using Medical History to Shape a Profession: The Ideals of William Osler and Henry E. Sigerist," Locating Medical History: The Stories and Their Meanings, yay. haz. Frank Huisman ve John Harley Warner (Baltimore \& London: The Johns Hopkins University Press, 2004) içinde, 144.

19 Heinz-Peter Schmiedebach, "Bildung in a Scientific Age," 78-79. 
1970'lerin sonlarına dek ilgi ve coşkuyla takip edilecek olan bu yaklaşım hekimler tarafindan, hekimler için, hekimlere ve onların dünya görüşüne dair bir tarihyazımı olarak tanımlanmaktadır. ${ }^{20}$ Elbette bu dönemde, farklı bir bakış açısıyla yazılan ve sadece hekimler için değil sağlık alanının diğer çalışanlarının da ilgisini çekebilecek istisna kitaplar da yayımlamıştır. Bunlardan biri, George Rosen'in 1958 yılında yayımlanan, Antik Yunan'dan İkinci Dünya Savaşı'na uzanan geniş bir dönemi ele alan A History of Public Health (Halk Sağlı̆̆ Tarihi) isimli eseridir. ${ }^{21} \mathrm{Bu}$ kapsamlı kitap, yöntemi ve içeriği bakımından, hem tıp tarihi alanında araştırma yapacak kişiler için bir örnek metin olmuş, hem de halk sağlığına dair çalışmalarda göreli olarak bir artışa sebep olmuştur. Kadın ve çocuk sağlığı, akıl sağlığı, kitlesel sağlı eğitimi ve hemşirelik gibi yeni çalışma konuları ortaya çıkmış ve tıp ve sağlık tarihi sosyal politika çalışmaları, emek tarihi ya da kadın tarihi gibi farklı alanlar içerisinde de kendine yer bulmaya başlamıştı. ${ }^{22}$

George Rosen, 1967 yılında Amerikan Tıp Tarihi Vakfı'nın yıllık toplantısında tıp tarihinin üslubunu yeniden tanımlamayı, tıbbın toplumsal bağlamını gündeme getirerek hasta merkezli bir yaklaşımı önermişti. ${ }^{23}$ Tıbbın toplumla olan ilişkisinin en önemli boyutunu oluşturan salgın hastalıkların tarihini ya da genel olarak hastalık tarihini ele alan çalışmalar tıp tarihi yazımında yeni bir kulvar açtı. Charles Rosenberg'in The Cholera Years (Kolera Yılları) ve Richard Evans'in Death in Hamburg (Hamburg'da Ölüm) eserleri, ilerleyen yıllarda sayısı artacak olan hastalık tarihi çalışmalarının habercisi olmuştu. ${ }^{24}$ Koleradan başka sarıhumma, tüberküloz, frengi, sıtma, trahom, kanser ve AIDS gibi pek çok hastalık hakkında da çalışma yapılmaya başlandı. ${ }^{25}$ Tıbbın tarihine ve yazımına yönelik daha köklü bir değişim ise Michel Foucault'nun çalışmaları, eleştirileri ve özellikle biyopolitika ${ }^{26}$ kavramı çerçevesinde öne sürdüğü görüşlerle ortaya çıkmaya başladi.

20 Martin Dinges, "Social History of Medicine in Germany and France in the Late Twentieth Century: From the History of Medicine toward a History of Health," Locating Medical History: The Stories and Their Meanings, yay. haz. Frank Huisman ve John Harley Warner (Baltimore \& London: The Johns Hopkins University Press, 2004) içinde, 209.

21 George Rosen, A History of Public Health (Baltimore and London: The Johns Hopkins University Press, 1993). Dorothy Porter bu kitabın mortalite oranlarında büyük düşüşler olmasından ötürü halk sağlığının "muzaffer gibi göründüğ̈̈" bir dönemde basıldığını söylemektedir, o nedenle de anlatılar, "büyük ilerleme anlatıları"ndan oluşmaktadır. Bu bakış açısı 1976'da Thomas McKeown'un The Modern Rise of Population (Nüfusun Modern Yükselişi) isimli kitabında yinelenmiştir. Tüm bunların anlamı, halk sağlığının sağlık reformları ile gerçekleştirilebileceği anlayışının yerleşmesidir. Thomas McKeown, The Modern Rise of Population (London: Edward Arnold, 1976), 1; Elizabeth Fee, "Public Health, Past and Present: A Shared Social Vision," A History of Public Health, yay. haz. George Rosen (Baltimore \& London: The Johns Hopkins University Press, 1993) içinde, xi.

22 Fee, "Public Health, Past and Present," xxxvii.

23 Mary Lindemann, Erken Modern Avrupa'da Tip ve Toplum, 17.

24 Richard J. Evans, Death in Hamburg: Society and Politics in the Cholera Years, 1830-1910 (Oxford: Oxford University Press, 1987); Charles E. Rosenberg, The Cholera Years: The United States in 1832, 1849, and 1866 (Chicago: University of Chicago Press, 1962).

25 Fee, "Public Health, Past and Present," xxxviii.

26 Foucault, on sekizinci yüzyıldan itibaren kapitalizmin öncelikle, ilk olarak iş gücündeki potansiyeli toplumsal olarak kontrol etmeyi amaçlamasını anlatmaktadır. Toplumsal kontrolun üzerinde tezahür ettiği zemin artık biyopolitik olarak adlandırdığı bir öze sahip olan bedendi. 


\section{Biyopolitika ve Yeni Tıp Tarihi}

Tarihçiler ile toplum kuramcıları her zaman dirsek teması içinde olmuşlardı fakat 1960'lı yıllarda artık “sızıntı, sel halini” almıştı. ${ }^{27}$ Böyle bir yazın ortamında, Foucault'nun 1963 'te yayımlanan The Birth of the Clinic (Kliniğin Doğuşu) adlı kitabı ile birlikte tarihçilerin ilgisi hastaneler ve kliniklere yönelmeye başlamıştı. Foucault, bir klinik deneyim alanı olarak hastanenin yeniden düzenlenmesini, hasta ve toplum ilişkisinin yeniden tanımlanmış olmasına bağlıyordu. ${ }^{28}$ Her ne kadar biyopolitika kavramının mucidi olmasa da, 1970'lerin sonundan itibaren verdiği seminerler, biyopolitika kavramının sosyal bilimler alanındaki etkisini artırmıştı. ${ }^{29}$

Foucault'ya göre modern dönemin niteliğini belirleyen şey, tıbbi baklşın varlığ idi. ${ }^{30}$ On dokuzuncu yüzyılda tıp, tıbbi bakış ve normalleştirilmiş bilgiyi üretme imkânı bulmuştu. Artık sadece hastalıklar değil, bu hastalıklara ev sahipliği yapan bedenler de tıp tarafından üretilebilir birimler halini almış; toplumsal bedenin bu şekilde üretimi okullarda, hapishanelerde, kışlalarda, atölyelerde ve hastanelerde uygulanan tekniklerle sürdürülebilir hale gelmişti. ${ }^{31} \mathrm{Bu}$ durumda on yedinci yüzyılın tıbbından farklı olarak daha sonraki yüzyıllarda uygulanan tıp, mesleğin bizatihi kendi iyileştirici ve koruyucu görevleriyle beraber, normalleştirmeye yönelik bir uygulama biçimi olarak ortaya çıkıyordu. ${ }^{32}$

“Kliniğin Doğuşu” tıp tarihçileri üzerinde 1980’li yıllara kadar ancak kısıtlı bir etki yaratabilmişti. On dokuzuncu yüzyıl beden söylemi üzerine çalışan Philipp Sarasin'in Foucault'nun fikrini geliştirerek söylem tartışmasını tıp tarihi alanına açması önemli bir başlangıç olmuştu. ${ }^{33}$ Söylem kavramı bu tarihten sonra tıp ile doğrudan ilişkilendirilir olmuş, Foucault'nun çalışmaları tıbbi iktidar, bilimsel bilginin gücü, cinsel devrim gibi siyasi pratiğe yönelik eylemlerde yahut liberalizm ve neo-liberalizme yönelik eleştiriler getiren, etik, yönetilenin hakları gibi konuları ele alan siyasi teorilerde görülür hale gelmişti. ${ }^{34}$

27 Peter Burke, Tarih ve Toplumsal Kuram, çev. Mete Tunçay (İstanbul: Tarih Vakfi Yurt Yayınları, 2000), 16-17.

28 Christiane Sinding, "The Power of Norms: Georges Canguilhem, Michel Foucault, and the History of Medicine," Locating Medical History: The Stories and Their Meanings, yay. haz. Frank Huisman ve John Harley Warner (Baltimore \& London: The Johns Hopkins University Press, 2004) içinde, 270.

29 Onur Kartal, "Giriş: Biyopolitikanın İzini Felsefe Tarihinde Sürmek," Biyopolitika, Cilt 1, yay. haz. Onur Kartal (Ankara: NotaBene Yayınları, 2016) içinde, 7.

30 Michel Foucault, The Birth of the Clinic: An Archaeology of Medical Perception (London: Tavistock Publications, 1973), 4.

31 David Armstrong, "Bodies of Knowledge/Knowledge of Bodies," Reassessing Foucault: Power, Medicine and the Body, yay. haz. Colin Jones ve Roy Porter (London \& New York: Routledge, 1998) içinde, 20.

32 Sinding, "The Power of Norms," 272.

33 Philipp Sarasin, Reizbare Maschinen. Eine Geschichte des Körpers, 1765-1914 (Frankfurt: Suhrkamp, 2001). Dinges, "Social History of Medicine in Germany and France," 225.

34 Mitchell Dean, Critical and Effective Histories: Foucault's Methods and Historical Sociology (London \& New York: Routledge, 1994), 178. 
Foucault'nun temelde söylediği şey, devlet ve toplum arasında tesis edilmiş olan ilişkinin doğasının on sekizinci yüzyılda değişmiş olduğuydu. Artık yönetici elitler nüfusun bizzat kendisini iktidar etme biçimlerinin en önemli alanı olarak görmeye başlamışlard $1{ }^{35}$ İdari teknikler on dokuzuncu yüzyılda dönemin ihtiyaçlarına cevap verebilecek biçimde öyle değişmişti ki devlet artık nüfusun üretken kapasitesi ile birebir ilgilenmeye başlamıştı. Böylelikle nüfusun bekası, refahı, nitelik ve niceliği yine devletin ilgi alanına giriyordu, bu da Foucault'nun terminolojisinde yönetimsellik sözcüğü ile karşılık buluyordu: Toplumsal meseleler de devletin faaliyet gösterdiği alanın içine dâhil edilmiş oluyordu.

Toplumsal olanın bilimsel bilgi ve teknik müdahalenin alanı olarak ortaya konması ise Batı bedenlerinin tarihinde bir dönüm noktası olmuştu. Toplumsalın alanında artık tehlikeli, sakat, muhtaç, hastalıklı, verimsiz ve "riskli" sınıflandırmasına giren kadın ve erkek bedenleri kol gezmekteydi. Burada da hükümet etme, toplumun ihtiyaçları doğrultusunda sağlıklı ve sağlıksızı birbirinden ayırma rolü oynamaktaydı. Aradaki bu ayrım bireysel bedenin yerine toplumsal bedeni ortaya koyan biyopolitikayı doğurmuştu. ${ }^{36}$

Biyopolitika kavramı mikro iktidar mekanizmalarını tartışmaya imkân veriyor, tüm toplumlara öyle ya da böyle ulaşmakta ve hepsini etkilemekte olduğu düşünülüyordu. ${ }^{37}$ Foucault için bedenler, hem üzerinde hem de hakkında söylem ve bilginin yürütüldüğü ve gerçekliklerin temsil edildiği nesnelerdi. ${ }^{38}$ Böylelikle tıbbın tüm alanları hekimiyle, hastasıyla, kurumlarıyla ve hükümetiyle bir iktidar alanının parçaları haline gelmekteydi. ${ }^{39}$

Toplumsal ve bilimsel bilginin, yani uzmanlığın ortaya çıkışı ile insanların faaliyetlerine müdahale etme imkânı daha evvelden görülmemiş bir şekilde artmıştı. Uzmanlar toplumsal alanın temel bir parçası haline gelmiş ve böylelikle hekimlik, öğretmenlik gibi mesleklere mensup olanların bireyleri kendi teknik bilgileri doğrultusunda sınıflandırmaları ve bazılarını bu sınıflandırmaların dışında bırakmaları, yani normal olan ile olmayanı tayin edebilmeleri mümkün olmuştu. Artık sağlıklı addedilebilmenin yolu da belli bir normun sınırları içinde kalabilmekten geçiyordu. ${ }^{40}$

35 Colin Gordon, "Governmental Rationality: An Introduction," The Foucault Effect: Studies in Governmentality, yay. haz. Graham Burchell, Colin Gordon ve Peter Miller (Chicago: The University of Chicago Press, 1991) içinde, 20 .

36 David Horn, Social Bodies: Science, Reproduction, and Italian Modernity (Princeton: Princeton University Press, 1994), 18.

37 Dean, Critical and Effective Histories, 175.

38 Elizabeth Grosz, Volatile Bodies: Toward a Corporeal Feminism (Bloomington: Indiana University Press, 1994), 146-49.

39 John Pickstone, "Medicine, Society, and the State," The Cambridge Illustrated History of Medicine, yay. haz. Roy Porter (Cambridge \& New York: Cambridge University Press, 1996) içinde, 304.

40 Sinding, "The Power of Norms," 264. 
Eğer beden bu şekilde tanımlanıyorduysa, yeniden icat edilmesi de gerekmekteydi. ${ }^{41}$ Sistemin taşıyıcıları sıfatıyla bu bedenlerin biyolojik varlıkları, siyasal varlıklarının nişanesi niteliğindeydi. ${ }^{42}$ Böylece toplumsal beden aynı zamanda siyasal beden haline de geliyordu. $\mathrm{O}$ halde, şu ya da bu şekilde bedenin siyasal otorite tarafindan onaylanması ihtiyacı ortaya çıkıyor, toplumsal bedenin korunması ya da birey-toplum ilişkilerinin yeniden tanımlanması gerekiyordu. ${ }^{43}$

Tüm bu anlatılanların 1şı̆̆ında, toplumsal bedenin idare edilmesi, bireylerin -ve dolayısıyla toplumun- üretken kapasitesinin arttırılmasının nihai hedef alındığını söylemek mümkün olmaktaydı. Düzenleyici pratikler doğum ve ölüm, sağlık durumu, yaşam beklentisi gibi alanlar üzerinde yoğunlaşmaktaydı. Aile de hem gelecek neslin hem de mevcut siyasetin teminat altına alındığı bir beşik haline gelmişti. On dokuzuncu yüzyıldan itibaren kadın ve çocuklar artık ayrı bir konuma yerleştirilmiş ve toplumsal birer nesne haline getirilmişler; sağlık ve beden terbiyesi yeni bir alan olarak kitleleri idare etmede önemli bir rol oynamıştı. "Tıbbileşen aile" normalleştirmelerin de bir aracı olmuştu. Artık doğan her çocuğun bedeni üzerindeki tasarruf hakkı tıbbi bilgi ve teknolojinin de üzerine geçmekteydi. Sonuç olarak Foucault, tıbbı ilerlemeci bilimsel gelişmeler silsilesi olmaktan çıkarmış, toplumsal ve siyasal güçlerin manevra yaptığı bir alanın içine dâhil etmişti. Bu da, tıbbın tarihinin -günahıyla sevabıyla- yeniden ve bambaşka bir biçimde yazılabilmesinin önünü açmıştı.

\section{Sosyal Tip Tarihi}

Sadece Michel Foucault değil, sosyolog Bryan Turner ve tarihçi Roy Porter'ın Batı Avrupa ve A.B.D. tarihyazıcılığında bedene özel bir önem atfetmesinin de, bedene ilişkin yeni bakış açılarının geliştirilmesinde dönüştürücü etkisi olmuştu. ${ }^{44}$ Yine de unutmamak gerekir ki tıp tarihi her zaman hasta olan bedenle ilgilenmişti. Norbert Elias'ın The Civilizing Process (Uygarlık Süreci)'inden ilk kuşak Annales okulu tarihçilerine, beden zaten genel olarak masaya yatırılmaktayd $1{ }^{45}$

İlk profesyonel sosyal tıp tarihçileri dalgası, yeni sosyal tarih ile işbirliği yapmaktaydı. ${ }^{46}$ Henry E. Sigerist tıp tarihçisini "tarih disiplininin yöntemleri ile yetişmiş hekim” olarak tanımlayarak - her ne kadar tıp tarihini hâlâ hekimlerin alanı olarak görmekteydiyse de - sosyal tıp tarihinin öncülerinden olmuştu. ${ }^{47}$ Sigerist'e göre eski tıp tarihçiliği eleştirel olmaktan uzaktı, üstelik tıp alanının içinden besleniyordu. Kitaplar içlerindeki olguları anlamak için okunuyor,

41 Armstrong, "Bodies of Knowledge/Knowledge of Bodies," 23.

42 Michel Foucault, Discipline and Punish: The Birth of the Prison (New York: Vintage Books, 1995), 142.

43 Grosz, Volatile Bodies: Toward a Corporeal Feminism, 117; Horn, Social Bodies, 44.

44 Mark Jenner ve B. Taithe, "The Historiographical Body," Companion to Medicine in the Twentieth Century, yay. haz. Roger Cooter ve John Pickstone (London: Routledge, 2003) içinde, 187-188.

45 A.g.e., 188.

46 A.g.e., 190.

47 Ronald L. Numbers, "The History of American Medicine: A Field in Ferment," Reviews in American History 10, 4 (1982): 245 . 
yazıldıkları bağlamlar dikkate alınmıyordu. ${ }^{48}$ Sigerist çoğu büyük tıbbi buluşun bilindiğini, buna mukabil bu buluşların gerçekten uygulanıp uygulanmadığının, uygulandıysa bile kimlere uygulanmış olduğunun bilinmediğini söylüyordu. Tıbbi eylem söz konusu olduğunda tıbb1 ilgilendiren iki grup bulunmaktaydı, bunları dar anlamda hekim ve hasta, geniş anlamda ise sağlık ekibi ve toplum olarak adlandırmaktaydı. Tıp, bu iki grup arasındaki çeşit çeşit ilişkiden ibaretti. Sigerist böylelikle tıp tarihini sosyal tarihin alanı haline getirmekteydi. ${ }^{49}$

Sigerist, yüzyılın ilk yarısında dünyanın en saygıdeğer tıp tarihçilerinden olarak kabul edilmekteydi. 1932'de Leipzig'den Amerika'ya taşınarak, Johns Hopkins Üniversitesi Tıp Tarihi Enstitüsü’nün müdürü olduğunda buraya Alman yaklaşımını getirmiş, Amerikan Tıp Tarihi Derneği'ni (American Association for the History of Medicine) örgütlemiş ve Bulletin of the History of Medicine dergisinin çıkarılmasını sağlamıştı. ${ }^{50}$ 1934-35 akademik yılında tıbbın toplumsal veçheleri üzerine bir ders programı üzerinde çalışmış ve bu çalışmanın sonucunda dört ciltlik ve konuları bir sosyal bilim olarak tıp, sağlık güvencesi, hükümet tabipliği, muhtelif ülkelerin sorunları gibi başlıklarda toplanan "Tıp Sosyolojisi”" isimli eser ortaya çıkmıştı. ${ }^{51}$ Yeni tıp tarihi, Henry Sigerist ve aynı enstitüdeki meslektaşı Owsei Temkin için yeni tıp tarihi, bir fikir tarihi alanı idi..$^{52}$

Siegerist, önemli bilim tarihi dergilerinden biri olan Isis' in kurucusu ve Introduction to the History of Science' in (Bilim Tarihine Giriş) yazarı George Sarton'un iddiasının aksine, tıbbın bilimin bir alt kolu olduğunu reddediyordu. Hekimin görevi hastalığ i iyileştirmek; tıp tarihinin ilgi alanı da hekim ile hasta ve idareciler, halk sağlığı uzmanları, bilim insanları, hemşireler, rahipler, sahte hekimler gibi sağlık alanının çalışanları ile toplum arasındaki ilişkilerdi. Tüm bunlar bilimsel yöntemlerin uygulanmasını içerse de, aynı zamanda toplumsal, ekonomik, siyasi ve dini faktörlerin de göz önünde bulundurulmasını gerektiriyordu. ${ }^{53}$

İkinci Dünya Savaşı'nı izleyen yıllarda tıp tarihi artık gelişmiş bir disiplindi ve sadece tıbbi ya da teknik eğitim değil, tarih eğitimi almış ya da almakta olan kişilerin ilgisini çekmekteydi. $\mathrm{Bu}$ yeni tıp tarihçileri grubunun eğitimleri klinik ve laboratuvardan ziyade tarih derslerinden ve seminerlerinden oluşmaktayd1. Elbette burada giderek artan bir şekilde bilime ve uzmanlaşmaya dayalı tıbbın, sağlığın insani yönünün kaybedilmesine yol açacağı endişesi de etkiliydi. ${ }^{54}$

48 Alan Brandt, "Emerging Themes in the History of Medicine, The Milbank Quarterly 69 (1991): 200.

49 James T. Patterson, "How Do We Write the History of Disease?," Health and History 1, 1 (1998): 5.

50 Theodore M. Brown ve Elizabeth Fee, "Henry E. Sigerist: Medical Historian and Social Visionary," American Journal of Public Health 93, 1 (2003): 60.

51 Numbers, "The History of American Medicine," 156.

52 John V. Pickstone, “A Brief History of Medical History,” erişim 17 Eylül 2019, http://www.History.Ac.Uk/ Makinghistory/Resources/Articles/History_of_Medicine.html; Vivian Nutton, "Oswei Temkin 1902-2002," Medical History 47, 1 (2003): 100-103.

53 Staffan Müller-Wille, "History of Science and Medicine," The Oxford Handbook of the History of Medicine, yay. haz. Mark Jackson (Oxford: Oxford University Press, 2011) içinde, 470.

54 Brandt, "Emerging Themes in the History of Medicine," 200. 
1950'lerin sonunda Contergan isimli bir ilacın yeterince test edilmeden sabah bulantılarını kesmek için hamile kadınlara verilmesinin doğum defektlerine sebep olduğuna işaret eden Thalidomide Faciası ile 1932-1972 yılları arasında frenginin doğal seyrini gözlemlemek için gerçekleştirilen ve bilgilendirilmemiş katılımcıların tedavisiz bırakılmalarından dolayı yaşam ya da sağlık kayıpları ile sonlanan Tuskegee Sifilis Çalışması gibi olaylar sonucunda tıbbın zarar verme potansiyeli kabul edilmeye başlandı. 1968 Hareketi’nin getirdiği eleştirellik sağlık alanına da yansımış, Ivan Illich'in Medical Nemesis (Sağlığın Gasp1), ${ }^{55}$ Susan Sontag' ın Illness as Metaphor (Metafor Olarak Hastalık)' 1 gibi çalışmalar sağlığın çeşitli veçhelerini tartışmaya açarak modern tıbbın etkililiğinin sorgulandığı yeni çalışmalara kapıyı aralamıştı. ${ }^{56}$ Illich, yaşamın her alanının tıbbın alanına dâhil edilmesi ve bizatihi modern tıbbi uygulamaların vaatlerinin tam tersine olumsuzluklar yaratıp zarar verdiği düşüncesini iatrojenez kavramı ile ortaya atıyordu. Sontag, hastalık metaforları vasıtasıyla belli bir kültürde ve belli bir anda değerlerin ve inançların doğasını inceliyordu. Burada yeni olan, hastaların hastalığı nasıl tecrübe ettiklerine ve nasıl algıladıklarına bakılmasıydı. Dolayısıyla Sontag'ın çalışması, hastalığın tarihsel tanımlarına dil, semboller ve ideolojiyi ekliyordu. ${ }^{57}$ Ayrıca antipsikiyatri akımının eleştirel zemini, sosyal tıp tarihçiliğini destekliyordu. ${ }^{58}$

Akademik ve klinik tıp tarihi akımlarının yüzleşmeleriyle beraber ${ }^{59}$ tıp tarihinin alanı ziyadesiyle genişlemişti; yoksulluk, gıdasızlık, önleyici tıp gibi konularla başlayan sosyal tıp tarihi giderek araştırma alanlarını genişletmekteydi. ${ }^{60}$ Savaş karşıtlığı, sosyal haklar ve kadın hareketi gibi toplumu dönüştüren tartışmalar ortaya atıldığında toplumla ilgilenen her alan gibi tıp tarihi de bu gelişmelerden etkilenmişti. Yeni kuşak tıp tarihçileri artık ırk, toplumsal cinsiyet, sınıf ve siyaseti göz önünde bulundurarak çalışıyorlardı. ${ }^{61}$ Dünya düzenini değiştirmenin yolu, “tarih bilimini” ve "toplumsal ve siyasal adaleti” birlikte düşünmekten geçiyordu. ${ }^{62}$

55 Ivan Illich, Medical Nemesis (London: Calder \& Boyars, 1974); Ivan Illich, Să̆lı̆̆ın Gaspı, çev. Süha Sertabipoğlu (İstanbul: Ayrıntı Yayınları, 2014); Roger Cooter ve Claudia Stein, "The End? History-Writing in the Age of Biomedicine (and before)," Writing History in the Age of Biomedicine, yay. haz. Roger Cooter ve Claudia Stein (New Haven \& London: Yale University Press, 2013) içinde, 21-22.

56 Susan Sontag, Illness as Metaphor and AIDS and its Metaphors (New York: Macmillan, 2001), Metafor Olarak Hastalık, AIDS ve Metaforları, çev. Osman Akınhay (İstanbul: Agora Kitaplı̆̆ı, 2005).

57 Brandt, "Emerging Themes," 203-204.

58 Kushner ve Leighton, "The Histories of Medicine," 116; Mervat Nasser, "The Rise and Fall of Anti-Psychiatry," Psychiatric Bulletin 19 (1995): 743-746.

59 Kushner ve Leighton, "The Histories of Medicine," 112.

60 Akademik tıp tarihyazımı daha 1970'li yıllarda klinik tıp tarihyazımını tümden reddetmenin olası sonuçları üzerinde tartışmaya başlamıştı. Karl Figlio, "The Historiography of Scientific Medicine: An Invitation to the Human Sciences," Comparative Studies in Society and History 19, 3 (1977): 262-286; Cherry, Medical Services and the Hospitals in Britain, 1860-1939, 3.

61 Susan M. Reverby ve David Rosner, " "Beyond the Great Doctors" Revisited: A Generation of the "New" Social History of Medicine," Locating Medical History: The Stories and Their Meanings, yay. haz. Frank Huisman ve John Harley Warner (Baltimore \& London: The Johns Hopkins University Press, 2004) içinde, 173.

62 Lindemann, Erken Modern Avrupa'da Tip ve Toplum, 16. 
1960'larda aralarında Charles Rosenberg, David Rothman, Barbara Rosenkrantz, James Cassedy, Diana Long, John Blake ve Gerald Grob'un da bulunduğu Amerikalı bir grup tıp tarihçisi Henry Sigerist ve Richard Shryock'un açmış oldukları yolu genişletmek için çabalamaya başlamıştı. Charles Rosenberg'in en temel talebi hekimlerin yaşamı, düşünceleri ve icraatlarıyla sınırlı bir yaklaşımdan; sosyoekonomik etkenlerle genişletilmiş, sosyal ve kültürel bağlamın dikkate alındığı bir anlayışa yönelmekti. ${ }^{63}$

Daha önce de bahsedildiği gibi alanda dönemin çığır açan kitabı, Charles Rosenberg'in 1962 yılında yayımladığı The Cholera Years (Kolera Yılları) isimli çalışmasıydı. ${ }^{64}$ New York'ta yayılan üç salgına verilen siyasal, toplumsal ve tıbbi tepkileri anlamaya çalışan Rosenberg hem hastalığın kentin doğasını, fiziksel çevresini ve kurumlarını etkilediğini, hem de salgın hastalık deneyimlerinin sadece tıp ve tıbbi bilgide değil, toplum ve siyasete dair her alanda aranabileceğini söylüyordu. Kitap tıp tarihyazımında hem devletin sağlık alanındaki rolünü, hem de hastalık durumunda sorumluluğun kim(ler)de olduğunu tartışmaya açmışt1. ${ }^{65}$ Rosenberg ve Janet Goldon'un derlemiş olduğu Framing the Disease (Hastalığı Çerçevelemek) kitabında ise sosyal, ekonomik ve kültürel güçlerin, toplumların hastalıkları anlama yollarını çerçevelediği anlatılıyor, dolayısıyla hastalık "toplumsal teşhis" ile ilişkilendiriliyordu. ${ }^{66}$

$\mathrm{Bu}$ gelişmelere dayanarak toplumsal cinsiyet, sınıf ve ırk tarihyazımının temel eksenleri, kadın sağlık çalışanları ise tarihin yeni aktörleri haline gelmişti. ${ }^{67}$ Toplumsal cinsiyete dair diğer meseleler ise üreme, bilimsel söylemler ve cinsellikti. Tarihçiler toplumsal cinsiyetin ve cinselliğin hangi şartlar altında ve neden biyoloji ile örtüştügünü giderek daha fazla sorgulamaya başlamıştı. ${ }^{68}$ Ebelere ilişkin çalışmalar ise toplumsal cinsiyet meselesinde iktidar ilişkilerinin tesisinin araştırılmasında kilit rol oynamaya başlamıştı. ${ }^{69}$

Toplumsal cinsiyete ilaveten sınıf da sosyal tıp tarihyazımının odak noktalarından biri haline gelmişti. 1980'lerin ortasında ve 1990’lı yıllarda kömür madenlerinde çalışanlar

63 Numbers, "The History of American Medicine," 258.

64 Rosenberg, The Cholera Years: The United States in 1832, 1849, and 1866 (Chicago: University of Chicago Press, 1962).

65 Brandt, "Emerging Themes," 202-203.

66 Bu fikre göre örneğin silikozis, kronik yorgunluk sendromu ve anoreksiya aslında çeşitli durumları tarif ediyor; histeri, alkolizm, eşcinsellik, hiperaktivite biyolojik patolojik mekanizmaların varlığının ispatlanmamasına rağmen, hastalıklar olarak etiketlenebiliyordu. James T. Patterson, "How Do We Write the History of Disease?," Health \& History 1 (1998): 9; Charles E. Rosenberg ve Janet Lynne Golden, Framing Disease: Studies in Cultural History (New Brunswick \& New Jersey: Rutgers University Press, 1992), xxii.

67 Tip, toplumsal cinsiyet ve beden çalışmalarının genel bir değerlendirmesi için bk. Delphine Gardey, "Writing the History of the Relations between Medicine, Gender and the Body in the Twentieth Century: A Way Forward?," Clio. Women, Gender, History 37 (2014): 1-21.

68 Reverby ve Rosner, "Beyond the Great Doctors," 179.

69 Dinges, "Social History of Medicine in Germany and France," 222. 
gibi sanayi işçileri sıklıkla konu edilmişti. Bu yeni tarih; toplumsal sınıflar, uzmanlar, dini ve bilimsel topluluklar ve devletler nezdinde salgın hastalıklara ilişkin çeşitli tecrübeleri incelemek anlamına da geliyordu: Halk sağlı̆̆1 1980'lerden sonra salgın hastalıkların karşısında kolektif ve bireysel tepkileri araştırmaktayd1. ${ }^{70}$ Özellikle Amerikan tarihyazımında 1rk da ziyadesiyle önemli bir kriterdi. ${ }^{71}$ Diğer bir deyişle, meczup, dilenci, yoksul, suçlu gibi o güne kadar sistemin kıyısında kalan kim varsa tarihin öznesi haline geliyordu. ${ }^{72}$

Bir diğer odak noktası ise bedenin kendisinin ve beden siyasetinin tartışmaya açılmasıydı. Almanya'da gazeteci Ernst Klee ile psikiyatrist Klaus Dörner'in Nazi dönemi hekimlerinin rolü üzerine kaleme almış oldukları rapor 1960'ların sonunda çokça tartışılmıştı. ${ }^{73}$ Sorunun temel ekseni iktidar ve firsat eşitsizliğiydi. 1990 ve 2000'lerde ise bu tartışmanın mutlaka sosyal bir boyutunun olması gerektiği fikri yaygınlaşmıştı. Artık tıp aynı zamanda hükümet etme, modernliğin getirdiği yeni teknikler ve idari bilginin sorgulanmasının da bir vasıtası olarak görülmeye başlanmıştı. ${ }^{74}$

Anatomi ve diseksiyon üzerine yapılan çalışmalar da bize yeni tıp tarihi ile beden tarihi çalışmaları arasındaki örtüşmeyi göstermişti. ${ }^{75}$ Sağlık, hastalık ve yaşam üçlemesi kavramı ortaya atılmış, ${ }^{76}$ bedenin bilginin bir nesnesi haline gelmesi tartışılmıştı. ${ }^{77}$ Tıbbın ve halk sağlığının tarihi yeniden tanımlanmıştı. Toplumların sağlık ve hastalığı nasıl tecrübe ettiğine, toplumsal, iktisadi ve siyasi sistemlerin sağlıklı ve sağlıksız bedenler için ne tür imkânlar yarattığına, toplumların hastalığın oluşumu ve aktarılması için ne gibi şartlar yarattığına ve insanların hem bireysel hem de toplumsal olarak sağlık durumlarını nasıl iyileştirip hastalıklardan kaçınma çabaları sergilediğine bakılıyordu. ${ }^{78}$

Özellikle AİDS'in ortaya çıkışıyla beraber bulaşıcı hastalıklar da yeniden masaya yatırılmıştı. ${ }^{79} \mathrm{Bu}$ hastalık, damgalamanın tarihsel incelenmesini canlandırmış, yeni sorular ortaya atmış, toplumsal inşanın gündelik hayattaki etkilerinin anlaşılmasında yeni tartışmalar açmışt1. ${ }^{80} 1988$ 'de Amerika'da Elizabeth Fee ve Daniel Fox'un derlediği AIDS: The Burdens

70 Dorothy Porter, Health, Civilisation and the State: A History of Public Health from Ancient to Modern Times (London: Routledge, 1999), 2.

71 Reverby ve Rosner, "Beyond the Great Doctors," 178-85.

72 Giovanna Procacci, "Social Economy and the Government of Poverty," The Foucault Effect: Studies in Governmentality, yay. haz. Graham Burchell, Colin Gordon ve Peter Miller (Chicago: The University of Chicago Press, 1991) içinde, 152.

73 Dinges, "Social History of Medicine in Germany and France," 211.

74 Nikolas Rose, "Medicine, History and the Present," Reassessing Foucault: Power, Medicine and the Body, yay. haz. Colin Jones ve Roy Porter (London \& New York: Routledge, 1998) içinde, 54-55.

75 Roy Porter, "The Historiography of Medicine in the United Kingdom," Locating Medical History: The Stories and Their Meanings, yay. haz. Frank Huisman ve John Harley Warner (Baltimore \& London: The Johns Hopkins University Press, 2004) içinde, 202.

76 Foucault, The Birth of the Clinic, 144.

77 Foucault, Discipline and Punish, 28.

78 Fee, "Public Health, Past and Present, xxxviii.

79 Dinges, "Social History of Medicine in Germany and France," 216.

80 Porter, Health, Civilisation and the State, 3. 
of History (AİDS: Tarihin Yükleri) isimli çalışma, geçmiş ve bugün arasındaki analojiler üzerinden yola çıkıyor ve geçmiş salgınların bu hastalıkla mücadelede bize söyleyebilecekleri olup olmadığına bakıyordu. ${ }^{81}$

Burada vurgulanması gereken önemli bir nokta da, sosyal tıp tarihi ile ilgileniyor olmanın tıp dünyasında bilimin yerini inkâr etmek anlamına gelmeyeceğidir. Aksine, tıpta bilimsel gelişmenin izini sürme faaliyeti bilimin tıbbın içindeki kültürel, toplumsal ve ekonomik rollerini temel alan bir çalışma yürütmeye doğru evrilmişti. Yine de klinik tıp tarihçileri bu gelişmelere olan tepkilerini gençlerin tıbbın alanının dışındaki konularla uğraştıklarını ve hekim olmayanların alana dâhil olduklarını ifade ederek göstermişlerdi. ${ }^{82}$ Journal of the History of Medicine' in editörü “tıp olmadan tıp” çalışıldığından şikâyet ediyordu. ${ }^{83}$

\section{Sonuç}

Bir yandan sosyal tıp tarihçiliği ile klasik tıp tarihçiliği arasındaki farklılıklar varlığını sürdürürken, tartışma zemini özellikle 2000'li yıllardan itibaren başka bir alana sıçramıştı: Sosyal tıp tarihçileri, bilim ve teknolojinin gelişmesiyle beraber tıbba bilimsel ve teknoloji odaklı bakışın yeniden canlanmasına yönelik endişelerini dile getirir olmuşlardı. Roger Cooter ve Claudia Stein bir derleme kitap yayımlayarak biyotıp çağında akademik tarihçiliğin üstesinden gelmesi gereken temel tehlikeyi vurguluyorlardı. Günümüzde, "paylaşılan biyolojik özellikler temelinde yeni öznelleşme ve kolektif eylem biçimleri”ne işaret eden "biyolojik vatandaşlık" gibi kavramlar; sosyoloji, antropoloji, toplum ve bilim çalışmaları gibi disiplinlerde tıbbın değerlendirilmesinde "toplumsal vatandaşlık" kavramının yerini almaya başlamıştı. Editörler, “insan-sonrası” kavramıyla tıbbın toplumsal veçhelerinin tartışılmasında biyolojik / nörolojik determinizmin akademiyi esir alabileceğini söylüyorlard1. ${ }^{84}$

Nihayetinde bugünkü tartışma, her ne kadar klinik ve akademik tıp tarihçilerinin mücadelesinin sürdüğünü gösterse de, arada kurulabilecek işbirliğinin öneminin de vurgulandığı bir zemine ilerlemiştir. ${ }^{85}$ Henüz 1989'da Avustralya Tıp Tarihi Derneği’nin

81 Virginia Berridge, "Contemporary History of Medicine and Health," The Oxford Handbook of the History of Medicine, yay. haz. Mark Jackson (Oxford: Oxford University Press, 2011) içinde, 118.

82 Numbers, "The History of American Medicine," 251.

83 Leonard Wilson, "Medical History without Medicine," Journal of the History of Medicine 35 (1980): 5-7.

84 Cooter and Stein, "The End? History-Writing in the Age of Biomedicine (and before)," 1-2. Ists'in bir y1l sonraki sayısında ise Warwick Anderson bu kitabı değerlendiren kitap eleştirisi yazısında editörleri tıp tarihinin Bolşevikleri olarak tanımlıyor ve tıp tarihçiliğinin politik savunuculukla özdeş görüldüğünü vurguluyordu. Foucault'dan ziyadesiyle etkilenmiş olduklarını gözlemlediği editörlerin postyapısalcı biyopolitika anlayışını savunurken temelinde Avrupamerkezcilik hatasına düştüklerini ifade ediyor ve postkolonyal teori, maduniyet çalışmaları gibi teorik yaklaşımların da, tıp tarihinin amaç ve yöntemlerinin açık seçik tartışılması gerektiği fikrinden yola çıkılarak kaleme alınan bir kitapta bulunması gerektiğini ifade ediyordu. Warwick Anderson, Isis 105, 2 (2014): 413-414.

85 Bugün tartışma, sosyal tıp tarihinin siyasal ve entelektüel olarak güncel sorunlara etki edip edemediği 
ilk ulusal konferansında Richard Gillespie artık çalışmaların olabildiğince fazla teknik bir yaklaşımdan beslenilerek gerçekleştirilmesi gerektiğini söylüyor ve bunun ancak açık yüreklilikle tıp ve tarih odaklı tıp tarihi çalışmalarının çeşitli hedeflerinin kabul edilmesiyle mümkün olabileceğini ifade ediyordu. Her iki akımın güçlü taraflarını alarak "bilateral” bir yaklaşımın teşkil edilebileceğini ekliyordu: Hekimler tıbbın bilimsel ve deneysel yanlarına karşı duyarlıydı, tarihçiler ise toplumsal bağlam ve toplumun tıbba yönelik algılarını ortaya koyabilirdi. Gillespie böyle bir durumda iki yaklaşımın birbiriyle bütünleşmesi yerine işbölümü yapmanın alan için en verimlisi olacağını söylüyordu. ${ }^{86}$

Kuschner ve Leighton 2013 yılında böylesi bir bütünleşme üzerinde daha büyük bir ciddiyetle durulması gerektiğini, her ne kadar pek çok zorlukla karşılaşılacağı bilinse de her iki yaklaşımın birbirinin tecrübelerinden istifade edebileceğini savunmuşlard1 ${ }^{87}$ Kuschner şöyle diyordu:

\begin{abstract}
Nasıl ki biyomedikal bilgi ile donatılmamış bir tıp tarihi savunulamazsa, tarihsel bağlamdan bihaber şekilde yapılan tıbbi araştırmalar da eksiktir. Bu iki alanı bir araya getirmek için on yıllardır olduğu gibi, işbirliğine dayalı bir ortam yaratma konusundaki zorluk devam etmektedir. Belki de bir çözüme ulaşmanın yolu akademik tarihçileri hasta bakımı ve tıbba, hekimleri tarihsel olarak belirlenmiş kültürler ve bağlamlarda tedavi ve araştırmanın ne ölçüde gerçekleştiğini takdir etmeye sevk eden türden bir eğitimi sunma çabasındadır. Böyle bir çaba doktorlar ve tarihçiler arasında heyecan verici ve üretken işbirliğinin temeli olabilir. $^{88}$
\end{abstract}

2014'te Health and History dergisinde konu ile ilgili genel bir değerlendirme yazıs1 çıkmıştı. Bu yazıda da ifade edilen, derginin en başından beri iki grubu işbirliğine teşvik etmenin amaçlandığı yönündeydi. Hekimlerin ve profesyonel tarihçilerin işbirliğiyle çıkarılan dergi, yazarlar ve okuyucular için bir buluşma alanı oluşturma konusunda kararlı bir taahhütte bulunmuştu. Bu iki grubun tarihsel çıkarları ve profesyonel kaygıları arasında üretken bir dengeyi korumak, tıp tarihi dergileri, dernekleri veya konferans düzenleyicileri için çoğu zaman kolay olmamış ve pek çoğu denemekten vazgeçmişti. Değerlendirme yazısı, derginin olgunluğa erişirken "tıp tarihinin Jön Türk'ü” olarak kendine özgü, cesur sesini kaybetmemesi temennileriyle sona eriyordu. ${ }^{89}$

yönündedir. Roger Cooter akımın ortaya çıktığı dönemlerden farklı olarak, bugünün ihtiyaçları karşısında kadük kaldığını, biyoloji merkezli çağımızda tıp merkezli tarihçilerin niteliklerinin daha uygun olduğunu ifade etmektedir. Roger Cooter, "After Death/after-'Life': The Social History of Medicine in Post-Postmodernity," Social History of Medicine 20, 3 (2007): 441-464. Ona cevaben gelen tartışmalar için bk. Jonathan Toms, "So What? A Reply to Roger Cooter's "after Death/after-'Life': The Social History of Medicine in PostPostmodernity," Social History of Medicine 22 (2009): 609-615.

86 Kushner ve Leighton, “The Histories of Medicine," 118-119.

87 A.g.e., 118-119.

88 Howard I. Kushner, "Medical Historians and the History of Medicine," The Lancet 372, 9640 (2008): 711.

89 Naomi Rogers ve John Harley Warner, "Remapping the History of Medicine: Fifteen Years of Health and History," Health and History 15, 2 (2013): 5. 
Sonuç olarak tıp tarihinin yazımı, farklı disiplinlerden araştırmacıların konuyu kendi perspektiflerinden tartıştığı zengin bir zemine doğru ilerlemiştir. Sosyal tıp tarihçiliğinin haricinde hem yeni teknolojiler hem de tıbbın yeni biçimlerde değerlendirilmeye başlanması sonucunda tarih, etik, sosyoloji, bilim ve teknoloji çalışmaları gibi alanlar çeşitli işbirliği zeminleri arayışına girmişlerdir.

Yirminci yüzyılın son çeyreğinden itibaren hastalık ve sağlık konularına bir toplumsal mesele olarak odaklanan bir akım ortaya çıkmıştır. Genel tarihyazımı ile paralellik arz edecek şekilde önce pozitivizmden etkilenen tıp tarihyazımı, tıbbi bilginin kendine has özellikleri ve önceleri sadece tıbbi ilerlemelerin tarihi olarak tahayyül edilmesi nedeniyle genel tarihçilikten farklı olarak tarihçiler tarafından değil, tıbbi bilgiye en hâkim olan hekimler tarafından icra edilmiştir. 1960 ve 1970'li yıllardan itibaren ise hem klasik tarihyazımına getirilen eleştiriler sonucu tarihin yazılış biçimleri siyasetten toplumsal ve kültürel alanlara kaymış hem de tıbbın getirdiği gelişmeler, sağlığın toplumsal etkilerinin sorgulanmasına sebep olmuş, bu vesilelerle tıp tarihyazımı da sağlık alanında geçmişte olanın toplumsal ve kültürel karşılıklarını arar olmuştur. Bu nedenle de tarihi yazan ve yapanlar sadece hekimler olmaktan çıkmış; sağlık alanının diğer kadın ve erkek çalışanları ve tarihçiler başta olmak üzere diğer sosyal bilimcileri dâhil eder hale gelmiştir.

Kronik hastalıklar, sağlıkta eşitsizlikler, toplumsal ayrımcılık, sosyal politikalar gibi konulara dair yeni soru ve tartışmalar; bu konulara ilişkin geçmişteki örneklere bakarak güncel sorunlara cevaplar arama isteğini canlandırmış ve sağlık alanında eğitim görmemiş olan araştırmacıların giderek bu alana daha fazla ilgi duymasına sebep olmuştur. Hastalık ve sağlığın tüm açılardan incelenmesi ve tümüyle yeniden tanımlanması, buna dair yeni perspektiflerin ortaya konması elzem görülmeye başlanmış, tıp tarihi sosyal bilimcilerin gözünde giderek daha fazla önem kazanmıştır. Son olarak Mary Lindemann'ın sözleri ile başlayan makalemizi yine onunla bitirirsek; artık tıp tarihinin temel doğrultularından bir tanesi “tıp tarihinin 'genel tarihin bir parçası' olduğudur”. ${ }^{90}$

Hakem Değerlendirmesi: Dış bağımsız.

Çıkar Çatışması: Yazar çıkar çatışması bildirmemiştir.

Finansal Destek: Yazar bu çalışma için finansal destek almadığını beyan etmiştir.

Peer-review: Externally peer-reviewed.

Conflict of Interest: The author has no conflict of interest to declare.

Grant Support: The author declared that this study has received no financial support.

90 Lindemann, Erken Modern Avrupa'da Tip ve Toplum, 14. 


\section{KAYNAKÇA / BIBLIOGRAPHY}

\section{Basılı Kaynaklar / Printed Sources}

Anderson, Warwick. "Roger Cooter; Claudia Stein. Writing History in the Age of Biomedicine," Isis 105, 2 (2014): 413-14.

Armstrong, David. "Bodies of Knowledge/Knowledge of Bodies." Reassessing Foucault: Power, Medicine and the Body. Yayına hazırlayanlar Colin Jones ve Roy Porter içinde 17-27. London \& New York: Routledge, 1998.

Berridge, Virginia. "Contemporary History of Medicine and Health." The Oxford Handbook of the History of Medicine. Yayına hazırlayan Mark Jackson içinde 117-32. Oxford: Oxford University Press, 2011.

Brandt, Alan. "Emerging Themes in the History of Medicine." The Milbank Quarterly 69 (1991): 199-214.

Brown, Theodore M. ve Elizabeth Fee. "Henry E. Sigerist: Medical Historian and Social Visionary." American Journal of Public Health 93, 1 (2003): 60.

Burke, Peter. Tarih ve Toplumsal Kuram. Çeviren Mete Tunçay. İstanbul: Tarih Vakfi Yurt Yayınları, 2000.

Burke, Peter. Fransız Tarih Devrimi: Annales Okulu. Çeviren Mehmet Küçük. Ankara: Doğubatı, 2010.

Cherry, Steven. Medical Services and the Hospitals in Britain, 1860-1939. Cambridge \& New York: Cambridge University Press, 1996.

Cooter, Roger. "After Death/after-'Life': The Social History of Medicine in Post-Postmodernity." Social History of Medicine 20, 3 (2007): 441-64.

Cooter, Roger ve Claudia Stein. "The End? History-Writing in the Age of Biomedicine (and before)." Writing History in the Age of Biomedicine. Yayına hazırlayanlar Cooter, Roger ve Claudia Stein içinde 1-40. New Haven \& London: Yale University Press, 2013.

Dean, Mitchell. Critical and Effective Histories: Foucault's Methods and Historical Sociology. London \& New York: Routledge, 1994.

Dinges, Martin. "Social History of Medicine in Germany and France in the Late Twentieth Century: From the History of Medicine toward a History of Health." Locating Medical History: The Stories and Their Meanings. Yayına hazırlayanlar Frank Huisman ve John Harley Warner içinde 209-36. Baltimore \& London: The Johns Hopkins University Press, 2004.

Evans, Richard J. Death in Hamburg: Society and Politics in the Cholera Years, 1830-1910. Oxford: Oxford University Press, 1987.

Fee, Elizabeth. "Public Health, Past and Present: A Shared Social Vision." A History of Public Health. Yayına hazırlayan George Rosen içinde ix-lxvi. Baltimore \& London: The Johns Hopkins University Press, 1993.

Fee, Elizabeth ve Theodore M. Brown. "Using Medical History to Shape a Profession: The Ideals of William Osler and Henry E. Sigerist." Locating Medical History: The Stories and Their Meanings. Yayına hazırlayan Frank Huisman ve John Harley Warner içinde 139-64. Baltimore and London: The Johns Hopkins University Press, 2004.

Figlio, Karl. "The Historiography of Scientific Medicine: An Invitation to the Human Sciences." Comparative Studies in Society and History 19, 3 (1977): 262-86.

Foucault, Michel. The Birth of the Clinic: An Archaeology of Medical Perception. London: Tavistock Publications, 1973. 
- Discipline and Punish: The Birth of the Prison. New York: Vintage Books, 1995.

Gardey, Delphine. "Writing the History of the Relations between Medicine, Gender and the Body in the Twentieth Century: A Way Forward?.” Clio. Women, Gender, History 37 (2014): 1-21.

Gordon, Colin. “Governmental Rationality: An Introduction.” The Foucault Effect: Studies in Governmentality. Yayına hazırlayanlar Graham Burchell, Colin Gordon ve Peter Miller içinde 1-51. Chicago: The University of Chicago Press, 1991.

Gourevitch, Danielle. "Charles Daremberg, His Friend Emile Littré, and Positivist Medical History.” Locating Medical History: The Stories and Their Meanings. Yayına hazırlayanlar Frank Huisman ve John Harley Warner içinde 53-73. Baltimore \& London: The Johns Hopkins University Press, 2004.

Grosz, Elizabeth. Volatile Bodies: Toward a Corporeal Feminism. Bloomington: Indiana University Press, 1994.

Horn, David. Social Bodies: Science, Reproduction, and Italian Modernity. Princeton: Princeton University Press, 1994.

Iggers, Georg G. Bilimsel Nesnellikten Postmodernizme Yirminci Yüzyılda Tarihyazımı. Çeviren Gül Çağalı Güven. İstanbul: Tarih Vakfı Yurt Yayınları, 2000.

Illich, Ivan. Medical Nemesis. London: Calder \& Boyars, 1974.

Illıch, Ivan. Să̆lı̆̆ın Gaspı. Çeviren Süha Sertabipoğlu. İstanbul: Ayrıntı Yayınları, 2014.

Jenner, Mark ve B. Taithe. "The Historiographical Body." Companion to Medicine in the Twentieth Century. Yayına hazırlayanlar Roger Cooter ve John Pickstone içinde 187-200. London: Routledge, 2003.

Kartal, Onur. "Giriş: Biyopolitikanın İzini Felsefe Tarihinde Sürmek.” Biyopolitika, Cilt 1. Yayına hazırlayan Onur Kartal içinde 7-26. Ankara: NotaBene Yayınları, 2016.

King, Charles R. "The Historiography of Medical History: From Great Men to Archaeology." Bulletin of the New York Academy of Medicine 67, 5 (1991): 407-28.

Kushner, Howard E. ve Leslie S. Leighton. "The Histories of Medicine: Toward an Applied History of Medicine." Humanities in the Twenty First Century. Yayına hazırlayanlar Eleonora Belfiore ve Anna Upchurch içinde 111-136. London: Palgrave Macmillan, 2013.

Kushner, Howard I. “Medical Historians and the History of Medicine.” The Lancet 372, 9640 (2008): $710-11$.

Lammel, Hans-Uwe. "To Whom Does Medical History Belong? Johann Moehsen, Kurt Sprengel, and the Problem of Origins in Collective Memory." Locating Medical History: The Stories and Their Meanings. Yayına hazırlayanlar Frank Huisman ve John Harley Warner içinde 33-52. Baltimore \& London: The Johns Hopkins University Press, 2004.

Lindemann, Mary. Erken Modern Avrupa'da Tıp ve Toplum. Çeviren Mehmet Doğan. İstanbul: Boğaziçi Üniversitesi Yayınevi, 2013.

McKeown, Thomas. The Modern Rise of Population. London: Edward Arnold, 1976.

Müller-Wille, Staffan. "History of Science and Medicine." The Oxford Handbook of the History of Medicine. Yayına hazırlayan Mark Jackson içinde 469-83. Oxford: Oxford University Press, 2011.

Nasser, Mervat. "The Rise and Fall of Anti-Psychiatry.” Psychiatric Bulletin 19 (1995): 743-46.

Numbers, Ronald L. "The History of American Medicine: A Field in Ferment." Reviews in American History 10, 4 (1982): 245-63.

Nutton, Vivian. “Ancient Medicine: From Berlin to Baltimore.” Locating Medical History: The Stories and Their Meanings. Yayına hazırlayanlar Frank Huisman ve John Harley Warner içinde 115-38. Baltimore and London: The Johns Hopkins University Press, 2004. 
—_. "Oswei Temkin 1902-2002.” Medical History 47, 1 (2003): 100-03.

Patterson, James T. "How Do We Write the History of Disease?" Health and History 1, 1 (1998): 5-29.

Pickstone, John. "Medicine, Society, and the State." The Cambridge Illustrated History of Medicine. Yayna hazırlayan Roy Porter içinde 304-341. Cambridge \& New York: Cambridge University Press, 1996.

Porter, Dorothy. Health, Civilisation and the State: A History of Public Health from Ancient to Modern Times. London: Routledge, 1999.

Porter, Roy. "The Historiography of Medicine in the United Kingdom." Locating Medical History: The Stories and Their Meanings. Yayına hazırlayanlar Frank Huisman ve John Harley Warner içinde 194208. Baltimore \& London: The Johns Hopkins University Press, 2004.

Procacci, Giovanna. "Social Economy and the Government of Poverty." The Foucault Effect: Studies in Governmentality. Yayına hazırlayanlar Graham Burchell, Colin Gordon ve Peter Miller içinde 151-68. Chicago: The University of Chicago Press, 1991.

Reverby, Susan M. ve David Rosner. " "Beyond the Great Doctors” Revisited: A Generation of the "New" Social History of Medicine." Locating Medical History: The Stories and Their Meanings. Yayına hazırlayanlar Frank Huisman ve John Harley Warner içinde 167-93. Baltimore \& London: The Johns Hopkins University Press, 2004.

Rogers, Naomi ve John Harley Warner. "Remapping the History of Medicine: Fifteen Years of Health and History." Health and History 15, 2 (2013): 1-4.

Rose, Nikolas. "Medicine, History and the Present." Reassessing Foucault: Power, Medicine and the Body. Yayına hazırlayanlar Colin Jones ve Roy Porter içinde 48-72. London \& New York: Routledge, 1998.

Rosen, George. A History of Public Health. Baltimore \& London: The Johns Hopkins University Press, 1993.

Rosenberg, Charles E. The Cholera Years: The United States in 1832, 1849, and 1866. Chicago: University of Chicago Press, 1962.

Rosenberg, Charles E. ve Janet Lynne Golden. Framing Disease: Studies in Cultural History. New Brunswick \& New Jersey: Rutgers University Press, 1992.

Sarasin, Philipp. Reizbare Maschinen. Eine Geschichte Des Körpers, 1765-1914. Frankfurt: Suhrkamp, 2001.

Schmiedebach, Heinz-Peter. "Bildung in a Scientific Age: Julius Pagel, Max Neuburger, and the Cultural History of Medicine." Locating Medical History: The Stories and Their Meanings. Yayına hazırlayanlar Frank Huisman ve John Harley Warner içinde 74-94. Baltimore \& London: The Johns Hopkins University Press, 2004.

Sinding, Christiane. "The Power of Norms: Georges Canguilhem, Michel Foucault, and the History of Medicine." Locating Medical History: The Stories and Their Meanings. Yayına hazırlayanlar Frank Huisman ve John Harley Warner içinde 262-84. Baltimore \& London: The Johns Hopkins University Press, 2004.

Sontag, Susan. Illness as Metaphor and AIDS and Its Metaphors. New York: Macmillan, 2001. . Metafor Olarak Hastalı, AIDS ve Metaforları. Çeviren Osman Akınhay. İstanbul: Agora Kitaplığı, 2005.

Thompson, Edward Palmer. Avam ve Görenek: Ingiltere'de Geleneksel Popüler Kültür Üzerine Araştırmalar. Çeviren Mehmet Küçük. İstanbul: Birikim Yayınları, 2006.

Toms, Jonathan. "So What? A Reply to Roger Cooter's 'after Death/after-'Life': The Social History of Medicine in Post-Postmodernity'." Social History of Medicine 22, 3 (2009): 609-15. 
Toprak, Zafer. "Sosyal Tarih.” Tarih İçin Metodoloji. Yayına hazırlayan Ahmet Şimşek içinde 142-50. Ankara: Pegem Yayınları, 2016.

Wilson, Leonard. "Medical History without Medicine." Journal of the History of Medicine 35 (1980): 5-7.

Yazıcı, Fatih. "Tarihte Nesnellik ve Nedensellik." Tarih İçin Metodoloji. Yayına hazırlayan Ahmet Şimşek içinde 15-23. Ankara: Pegem Yayınları, 2016.

\section{Elektronik Kaynaklar / Electronic Sources}

Pickstone, John V. "A Brief History of Medical History.” Erişim 17 Eylül 2019. http://www.History.Ac.Uk/ Makinghistory/Resources/Articles/History_of_Medicine.html.

Gourevitch, Danielle. "Charles Victor Daremberg (1817-1872) et une Histoire positiviste de la Médecine." Erişim 26 Nisan 2020. http://www.biusante.parisdescartes.fr/histoire/medica/daremberg.php. 
